\title{
CAMA
}

Centre for Applied Macroeconomic Analysis

\section{China's electrical equipment manufacturing in the Global Value Chain: A GVC income analysis based on World Input-Output Database (WIOD)}

\section{CAMA Working Paper 26/2015 July 2015}

\section{Yingying Lu}

School of Economics, Shanghai University and

Centre for Applied Macroeconomic Analysis (CAMA), ANU

\begin{abstract}
This paper empirically analyzes China's electrical equipment manufacturing industry in the context of global value chain (GVC) by using the GVC income approach (Timmer et al., 2013) and the World Input-Output Database (WIOD). Four major questions are addressed by measuring several different indicators. China is found to have comparative advantage and competitiveness in terms of its large share of value added contribution in the world electrical equipment manufacturing industry. However, such competitiveness is not sustainable for two reasons: (1) China is actually a net value added importer, which limits its dominance and development in this industry; (2) the majority of China's GVC income comes from capital investment rather than high-skilled or valuable activities, which means the competitiveness is easy to be taken over as physical capital is more "mobile" than human capital. The paper also finds that the global financial crisis (GFC) did have certain impact on the electrical equipment GVCs in general, but the impact is not necessarily negative and big for each economy. For China, the GFC led to a decrease in the average real wage in this industry due to the decreasing high-skilled labor compensation share and the increasing low-skilled one. The analysis also implies that to upgrade the China's position in the electrical equipment manufacturing GVC may ultimately mean upgrading the agriculture sector such that more labor can be engaged in medium- and high-skilled activities.
\end{abstract}




\section{Keywords}

Global Value Chain (GVC), Input-Output Analysis, GVC income, China, Electrical Equipment Manufacturing

\section{JEL Classification}

C67, F14, L63

\section{Address for correspondence:}

(E) cama.admin@anu.edu.au

The Centre for Applied Macroeconomic Analysis in the Crawford School of Public Policy has been established to build strong links between professional macroeconomists. It provides a forum for quality macroeconomic research and discussion of policy issues between academia, government and the private sector.

The Crawford School of Public Policy is the Australian National University's public policy school, serving and influencing Australia, Asia and the Pacific through advanced policy research, graduate and executive education, and policy impact. 


\title{
China's Electrical Equipment Manufacturing in the Global Value Chain:
}

\section{A GVC income analysis based on World Input-Output Database (WIOD)}

\author{
Yingying Lu \\ ${ }^{1}$ School of Economics, Shanghai University, Shanghai 200444 China \\ Email: yingying_lu@shu.edu.cn \\ ${ }^{2}$ Centre for Applied Macroeconomic Analysis, Crawford School of Public Policy \\ Australian National University, Canberra 2601 Australia
}

\begin{abstract}
This paper empirically analyzes China's electrical equipment manufacturing industry in the context of global value chain (GVC) by using the GVC income approach (Timmer et al., 2013) and the World Input-Output Database (WIOD). Four major questions are addressed by measuring several different indicators. China is found to have comparative advantage and competitiveness in terms of its large share of value added contribution in the world electrical equipment manufacturing industry. However, such competitiveness is not sustainable for two reasons: (1) China is actually a net value added importer, which limits its dominance and development in this industry; (2) the majority of China's GVC income comes from capital investment rather than high-skilled or valuable activities, which means the competitiveness is easy to be taken over as physical capital is more "mobile" than human capital. The paper also finds that the global financial crisis (GFC) did have certain impact on the electrical equipment GVCs in general, but the impact is not necessarily negative and big for each economy. For China, the GFC led to a decrease in the average real wage in this industry due to the decreasing high-skilled labor compensation share and the increasing low-skilled one. The analysis also implies that to upgrade the China's position in the electrical equipment manufacturing GVC may ultimately mean upgrading the agriculture sector such that more labor can be engaged in medium- and high-skilled activities.
\end{abstract}

Key words: Global Value Chain (GVC); Input-Output Analysis; GVC income; China; Electrical Equipment Manufacturing

JEL codes: C67, F14, L63

The views expressed in the paper are those of the author and should not be interpreted as reflecting the views of any of the institutions with which the author is affiliated, including the trustees, officers or other staff of the Shanghai University and the Australian National University. 


\section{Introduction}

China has been called the "world factory" for its mass production of goods for the whole world. Since its entry into WTO in 2001, China's gross exports have grown more than 6 times by 2013. ${ }^{1}$ In particular, according to the WTO data ${ }^{2}$, China was the largest exporter of electronic data processing and office equipment and integrated circuits and electronic components in 2013 while it only ranked $10^{\text {th }}$ in the world in 1995. For China, electrical equipment is the largest export, even more than textile products which once ranked first on Chinese exports list. Therefore, China's electrical equipment industry is important not only for China but also for this industry in the world. However, as some recent studies have pointed out ,the domestic value added embodied in Chinese electrical equipment exports are actually low (about 30\% or less according to Koopman et al. (2012)). The label "Made in China" also implicitly says "cheap and low quality" for many people. In such context, the analysis based on exports data is no longer indicative; instead, the concept of "global value chain" is more suitable for such analysis.

Since the seminal work by Hummel et al. (2001), the concept of "vertical specialization" has been developed such that the "value chain" in business management has been extended to the "global value chain" (GVC) in a larger picture. In a review of GVC analysis, Gereffi and Fernandez-Stark (2011) identified four dimensions of GVC analysis: input-output structure, geographic scope, governance and institutional context. In the four dimensions, input-output structure is the basis for GVC analysis. However, due to the double accounting problem and multi-country production chain, the conventional trade data has become less reliable to measure the value contributed by a country (Johnson and Noguera, 2012). Therefore, measures, such as trade in value added (TiVA) and value added exports (VAX) ratio, are proposed (see Koopman et al., 2010, 2014 and Johnson and Noguera, 2012). Various measuring indicators are also defined to map the network or mechanism of the GVCs: for example, GVC_participation index and GVC_position index by Koopman et al. (2010); length index and upstreamness measure by Fally (2012) and Antràs et al. (2012). These studies heavily rely on the integration of national input-output tables and international trade data. However, their input-output data are mostly sourced from GTAP database which is not open to public access. More recently, the World Input-Output Database (WIOD) was constructed and published by a project funded by European Commission. It is not only open to public access but also contains other social economic accounts. This allows for comprehensive analyses of the world GVCs. Based on this database, Timmer et al. (2013) proposed the concept of GVC income and GVC jobs ${ }^{3}$ to analyze world GVCs.

This paper takes a comprehensive look at the electrical equipment manufacturing industry of China in the context of global value chain based on Timmer et al. (2013)'s GVC income framework using WIOD data. As in Backer and Miroudot (2013) and Timmer et al. (2013, 2015), one will need more than one indicator to assess the position of a particular country in the global value chain of a particular industry. In this paper, several questions are addressed

\footnotetext{
${ }^{1}$ Annual exports data is from National Bureau of Statistics of China, available at http://data.stats.gov.cn.

2 Based on data from WTO “Time Series on International Trade”, available at http://stat.wto.org/StatisticalProgram/WSDBStatProgramHome.aspx?Language=E.

${ }^{3}$ Timmer et al. (2013) define GVC jobs as "number of workers involved in the entire GVC”.
} 
by using different measures. First, the VAX ratio is computed to see how much value added China contributes in the exports of electrical equipment. Second, the revealed comparative advantage is used to answer how much China specializes in this industry; together with a ratio of intermediate value added exports to the total value added exports, we are able to identify the role of China in the global value chain. Third, we measure the competitiveness of China in this industry. A new measure, "contribution ratio" is defined based on the GVC income so that we can measure whether the competitiveness is "sustainable". Finally, we make use of the social economic accounts in the database to decompose the value added and the structure of employment. This helps us to justify why China sits in such a position as illustrated by the above indicators.

The study on the role of China's manufacturing industry in the global value chain is not a new topic in the literature (for example, Manova and Yu, 2012). A few studies use China as an example to illustrate the proposed measures of GVCs (for example, Koopman et al., 2012). However, few comprehensive analyses have been done on China's electrical equipment manufacturing industry from a GVC perspective. The contribution of this paper is therefore threefold. First, it provides a comprehensive analysis of China's electrical equipment manufacturing industry in the context of global GVC by using a new and consistent methodology-- the GVC income approach (Timmer at el., 2013). Second, the paper proposes a new measure-“contribution ratio"-based on the GVC income approach to describe the competitiveness of an economy in a global value chain from a new point of view. Third, the study not only addresses the questions in the global context but also shows the dynamic changes along the time axis by digging into several critical years.

The rest of the paper is organized as follows: Section 2 describes in detail the methodology and the data used in this study; the calculation formula and explanation of measuring indicators are presented in Section 3; Section 4 documents the results and discussions; and Section 5 concludes.

\section{Methodology and Data}

Our basic approach is to use the input-output analysis and GVC income analysis proposed by Timmer et al. (2013, 2015). The rationale of the methodology was similar to the one that is widely used for measuring indirect energy use and carbon embodied trade ${ }^{4}$. Thanks to the contribution from the World Input-Output Database (WIOD) project, this analysis method is revived from the literature and serves as a useful tool for analyzing the global value chain. The concept of GVC income also gives the IO analysis a new interpretation. A more detailed documentation of WIOD and its construction can be found in Dietzenbacher et al. (2013) as well as on the WIOD website. ${ }^{5}$ It is the only such database with public access and it provides various social economic accounts and environmental accounts corresponding to the data aggregation in their world input-output tables. The database now has covered 40 single major economies and a rest of the world (ROW) model that generates and incorporates the data of ROW into the tables. ${ }^{6}$ The full database contains data starting from 1995 till 2011; and future

\footnotetext{
${ }^{4}$ See e.g. Bullard and Herendeen (1975), Pick and Becker (1975), Bush (1981), Vringer and Blok (1995), Jiang and Liu (2015).

${ }^{5}$ http://www.wiod.org/new_site/home.htm

${ }^{6}$ Since Taiwan is in this database as one single economy, we use the term "economy" instead of "country" in this
} 
update may be expected.

In this study, we will use the complete world IO tables (40 economies plus ROW) and the variables in the social economic accounts, including labor and capital compensation. As the social economic accounts are in national currency which is not consistent with the measure in the world IO table that is measured in US dollar, we also use the gross output data in the social economic accounts to calculate the input share. We also make use of its labor compensation data by skill-type to explore the GVC employment structure. However, we don't use the full time span in the database; instead, we pick 1995, 2002, 2007 and 2009 to illustrate the dynamics. These time points have particular meaning to the Chinese economy. 1995 represents the early stage of China's “reform and opening” policy. 2002 was the first year since China's entry to the WTO in late 2001. The social economic accounts in WIOD only have data for China till 2009; therefore, we choose 2009 as the end year of our analysis. However, in 2009 the world economy, including China, experienced a big negative shock from the global financial crisis (GFC). Therefore, we also include 2007 to represent the pre-crisis period and also to compare with 2009 (post-crisis period). These particular years imply different stages of China's economic development.

The focus of this paper is China's electrical equipment manufacturing whose sector code is c14 in WIOD. As our analysis is in the global context, the comparison with other economies and the analysis of the value chains across the world is necessary. The economy abbreviation and sector aggregation follows the coding in WIOD, which is provided in the Appendix. Although WIOD includes 40 economies explicitly, some important economies in the electrical equipment GVCs are in the rest of the world (ROW), such as Singapore, Vietnam and Thailand. This may be a disadvantage of WIOD; but Taiwan may, to some extent, represent some features of these economies in the global electrical equipment manufacturing.

In conventional Input-Output analysis, the total output can be written in the form of matrix as follows:

$$
y=A y+f,
$$

where $\mathrm{y}$ is the vector of total output by sector, $\mathrm{A}$ is a square matrix of direct input coefficients for industries, $f$ is a vector of final demand. In the world IO table, the elements in matrix A not only include the domestic coefficients but also input coefficients from economy i's sector to economy j's sector $(i \neq j)$ as given in the WIO tables. Rearranging the equation, we can have:

$$
y=(I-A)^{-1} f,
$$

where I is an identity matrix and $(\mathrm{I}-\mathrm{A})^{-1}$ is the well-known "Leontief inverse" matrix. If we define a new coefficient vector $\mathrm{p}$ as the value added directly derived from one unit of gross output for each sector, then we can have the total value added decomposed as:

$$
v=\hat{p}(I-A)^{-1} \hat{f},
$$

where $\mathrm{v}$ is a square matrix that represents the value added flow across sectors and across economies; and the hat symbol on $p$ and $f$ means a diagonal matrix with the elements of $p$ or $f$ 
on the diagonal. Figure 1 is an illustration of the framework of GVC flows that is transformed from a world input-output table.

\begin{tabular}{|c|c|c|c|c|c|c|c|c|c|c|c|c|c|}
\hline & \multicolumn{10}{|c|}{$\begin{array}{l}\text { Final products of a global value chain, } \\
\text { identified by economy-industry of completion }\end{array}$} & \multirow{3}{*}{$\begin{array}{l}\text { Value } \\
\text { added }\end{array}$} \\
\hline & & & \multicolumn{3}{|c|}{ Economy 1} & \multirow[t]{2}{*}{$\cdots$} & \multicolumn{3}{|c|}{ Economy M } & \multicolumn{3}{|c|}{ ROW } & \\
\hline & & & $\begin{array}{c}\text { Industry } \\
1\end{array}$ & $\ldots$ & $\begin{array}{c}\text { Industr } \\
\text { y N }\end{array}$ & & $\begin{array}{c}\text { Industry } \\
1\end{array}$ & $\ldots$ & $\begin{array}{c}\text { Industry } \\
\mathrm{N}\end{array}$ & $\begin{array}{c}\text { Industry } \\
1\end{array}$ & 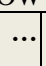 & $\begin{array}{c}\text { Industry } \\
\mathrm{N}\end{array}$ & \\
\hline \multirow{10}{*}{$\begin{array}{c}\begin{array}{c}\text { Value } \\
\text { added } \\
\text { from }\end{array} \\
\text { economy- } \\
\text { industries } \\
\text { participat } \\
\text { ing in } \\
\text { global } \\
\text { value } \\
\text { chains }\end{array}$} & \multirow{3}{*}{$\begin{array}{l}\text { Economy } \\
\quad 1\end{array}$} & Industry 1 & & & & & & & & & & & \\
\hline & & $\cdots$ & & & & & & & & & & & \\
\hline & & Industry $\mathrm{N}$ & & & & & & & & & & & \\
\hline & $\cdots$ & & & & & $\mathrm{v}_{\mathrm{ij}}(\mathrm{s}, \mathrm{t})$ & & & & & & & \\
\hline & \multirow{3}{*}{$\begin{array}{l}\text { Economy } \\
\mathrm{M}\end{array}$} & Industry 1 & & & & & & & & & & & \\
\hline & & & & & & & & & & & & & \\
\hline & & Industry $\mathrm{N}$ & & & & & & & & & & & \\
\hline & \multirow{3}{*}{ ROW } & Industry 1 & & & & & & & & & & & \\
\hline & & $\cdots$ & & & & & & & & & & & \\
\hline & & Industry $\mathrm{N}$ & & & & & & & & & & & \\
\hline \multicolumn{3}{|c|}{ Total final output value } & & & & & & & & & & & $\begin{array}{l}\text { World } \\
\text { GDP }\end{array}$ \\
\hline
\end{tabular}

Figure 1. Framework of GVC flows ${ }^{7}$

Although the format of Figure 1 is similar to an input-output table, the interpretation of the elements in Figure 1 is different. Each column represents a value chain of a specific final product (economy-industry-of-completion) and each cell indicates the origin and the amount of the value added into this value chain. Each row implies the contribution of a particular industry from a particular economy to all global value chains across the world. In other words, it is more like a global flow of value added through production and trade of products. The sum of all the rows is equal to the sum of all the columns, which also equals the world GDP. Each economy-industry cell $\mathrm{v}_{\mathrm{ij}}(\mathrm{s}, \mathrm{t})$ means the value added contributed by s economy i industry to $\mathrm{t}$ country $\mathrm{j}$ industry, where $\mathrm{s}, \mathrm{t}=1, \ldots, \mathrm{M}, \mathrm{ROW}$ and $\mathrm{i}, \mathrm{j}=1, \ldots, \mathrm{N}$.

Note that the interpretation can be varied by carefully choosing the p vector and f vector. In our study, we modify this $\mathrm{p}$ vector or $\mathrm{f}$ vector to derive different measurements. Following Timmer et al. (2015), the gross value added accounting is taken such that international transport margins and various taxes and subsidies are also included in our GVC calculation.

\section{Indicator Measurement}

To assess the position of China's electrical equipment manufacturing in the GVC, we measure some important indicators from different aspects based on the GVC income approach. It has been shown in previous studies that conventional indicator for measuring competitiveness as the shares in world exports market is not adequate in a more fragmented global production environment (Timmer et al. 2013). It is also notable that one single indicator, even based on GVC calculation, cannot describe an economy's position in the GVC of a particular product comprehensively. For example, Timmer et al. $(2013,2015)$ found that although the shares of domestic value added in manufacturing sectors in European Union have been decreasing rapidly since 1995 due to increasing international fragmentation in production there was actually a shift of jobs from manufacturing sector towards service sector and from low-skilled activities towards high-skilled activities. Therefore, in this paper five major measurements are provided, intending to better picture the China's electrical equipment industry in the global setting.

\footnotetext{
${ }^{7}$ This figure is adapted from Figure 3 in Timmer et al. (2015) by specifying rest of world (ROW) in the GVC framework.
} 
The first indicator used in this paper is the so-called VAX ratio, which is the ratio of the value added embodied in exports to the gross exports. This measurement is used in Johnson and Noguera (2012) and Koopman et al. (2014). It can also be found in the OECD database. Timmer et al. (2015) compared the statistics of VAX ratio from OECD database, Johnson and Noguera (2012) and Koopman et al. (2014) with the one calculated using WIOD for various countries in 2004. They concluded that there is remarkable agreement across these databases. The VAX ratio can tell us the domestic content of value added in the economy's exports, including the value added derived from final demand of the products and the intermediate use of the products in producing foreign final goods. To calculate this indicator, we separate VAX (value-added exports) into two parts: one is the value-added derived from intermediate inputs of Chinese electrical equipment in the final goods production elsewhere in the world; the other is the domestic value-added induced by foreign final demand of Chinese electrical equipment. The total VAX is the sum of VAX for all the industries in the economy.

The second measure is revealed comparative advantage (RCA). We adopt the concept of RCA which is originally formulated by Balassa (1965), but substitute exports with VAX in the formula. ${ }^{8}$ Therefore, the RCA index is measured as follows:

$$
\mathrm{RCA}_{\mathrm{i}}(\mathrm{s})=\frac{\operatorname{VAX}_{\mathrm{i}}(\mathrm{s}) / \sum_{\mathrm{i}} \mathrm{VAX}_{\mathrm{i}}(\mathrm{s})}{\sum_{\mathrm{s}} \operatorname{VAX}_{\mathrm{i}}(\mathrm{s}) / \Sigma_{\mathrm{s}} \sum_{\mathrm{i}} \mathrm{VAX}_{\mathrm{i}}(\mathrm{s})},
$$

where i refers to product, $\mathrm{s}$ is a set of country, and the full set in our study will represent the whole world. If RCA is larger than one, then it means this economy specializes in producing the product i relative to other economies in the GVC. The use of VAX instead of exports would make a difference as some industries may have a large exports share but not necessarily contain large share of added value in the exports. Electronic equipment manufacturing, for example, is such a typical industry due to its long value chain. The measure based on VAX can improve the measurement of RCA in the context of production fragmentation.

The third measurement is the competitiveness in terms of GVC income proposed by Timmer et al. (2013). Following Timmer et al. (2015), we measure the competitiveness by calculating the share of China's contributions to any electrical equipment production chain in the total value added of the world electrical equipment industry. This is different from the conventional competitiveness measured as "market share" in the world market. It is not only the scale of production but also the value added from the considered economy in any stage of global production of a particular product, including providing raw materials, producing components and conducting R\&D, etc.

However, the competitiveness is still not adequate to capture the position of one economy in the global value chain. For example, one economy may not be a large producer of a particular final product, but highly specialized in the upstream activities, such as design and R\&D. Then its total value added may not account for a big share in the world total value added in this industry; however, it does have the competitiveness in this industry as it owns the core

\footnotetext{
${ }^{8}$ In Timmer et al. (2013), they seem to use GVC incomes instead of exports in the original RCA index formula. They later explain that larger RCA may not necessarily imply that the country is also a major exporter of the product as it may add value to the GVC through upstream activities, or it may serve a large domestic market. However, in our measure, the influence of domestic market is eliminated as VAX does not include the value added induced by domestic demand. Therefore, the original concept of RCA is retained.
} 
technology to produce the product. On the contrary, an economy may be a large international producer in this industry which will rank high in the competitiveness measure; however, it may not be regarded as really "competitive" in this industry as they may be only good at producing the common parts of a product. Therefore, the concept of "competiveness" contains more dimensions, especially in the international production fragmentation.

As a complement, we define a new measure based on GVC income--contribution ratio (CR). It is to compare the contribution of value added from one economy to the world production of this product with the final output value added of this product from this particular economy. In other words, it contrasts how much value this economy adds to the world production (including the value added embodied in its intermediate exports) to how much value added its final product contains (including the value added embodied in the intermediate imports in its domestic value chain). The concept of CR is similar to but different from "GVC_Position" index proposed by Koopman et al. (2010). By using the GVC income approach, we take into consideration the total contribution of value added from an economy to all the GVCs of a particular product in the world, but not just value added embodied in the intermediate exports of the considered industry in other economies as defined in "GVC_Position" index.

The measurement can be expressed as follows:

$$
\mathrm{CR}_{\mathrm{i}}(\mathrm{s})=\frac{\sum_{\mathrm{j}, \mathrm{t}} \mathrm{v}_{\mathrm{ji}}(\mathrm{s}, \mathrm{t})}{\sum_{\mathrm{j}, \mathrm{t}} \mathrm{v}_{\mathrm{ji}}(\mathrm{t}, \mathrm{s})}
$$

where $v_{j i}(s, t)$ means the value added contributed from s economy j sector into t economy $i$ sector while $v_{j i}(t, s)$ means the value added contributed from t economy $j$ sector into $s$ economy $\mathrm{i}$ sector and $\mathrm{s}$ economy's $\mathrm{i}$ sector $\left(\mathrm{CR}_{\mathrm{i}}(\mathrm{s})\right)$ is the one we consider for this measurement. Such ratio does not make sense in an IO table or international trade data. The imports and exports are measuring different product value and the sum of which across industries does not make sense; however, in the contribution ratio based on GVC income, they are measured in value added, which makes the value added exports and imports directly comparable.

If the contribution ratio is larger than one, then it may have two possible cases. One is that the economy is not an economy-industry-of-completion such that the demand for its final output is small. The other is that the economy is engaged in high-value-added activities or in many stages of the production process, which indicates a strong dominance in this industry in the world. If we combine the competiveness indicator with this contribution ratio, then we can identify which case a particular country belongs to.

Finally, it is also helpful to look at the structure of GVC incomes by decomposing the income factors. As the data of the "number of employees" (EMPE in WIOD) in each sector for China is absent in the database, we use another data "number of persons engaged" (EMP in WIOD) in the database to approximate the employment generated by this industry. Combined with the value terms, an indicator similar to "real wage" is also computed.

With a comprehensive assessment by various indicators above across time and across other major economies in this industry, it can be helpful to position the development of China's electrical equipment manufacturing in the global value chain. 


\section{Results and Discussions}

\subsection{How much value added does China contribute in its exports?}

First, we calculate the VAX ratio both on the economy level and on the electrical equipment manufacturing sector level. The results are in Figure 2 and Figure 3. The economies are ranked by VAX ratio in 1995. It is notable that most economies, including China, witness a decline of VAX ratio in aggregate country level from 1995 to 2009 (see Figure 2). This may be, in general, due to the increasing production fragmentation and globalization in the world manufacturing sectors. China has a relatively high VAX ratio (84\% in 1995 and 79\% in 2009) among this economy group. Countries such as Brazil, Russia and Indonesia are unexpectedly high in VAX ratio while the ratios of Luxemburg, Belgium and Ireland are surprisingly low. However, it is also notable that most economies experienced an increase of VAX ratio from 2007 to 2009, which implies that the global financial crisis (GFC) actually had a positive shock on the VAX ratio while it gave the exports a negative shock.

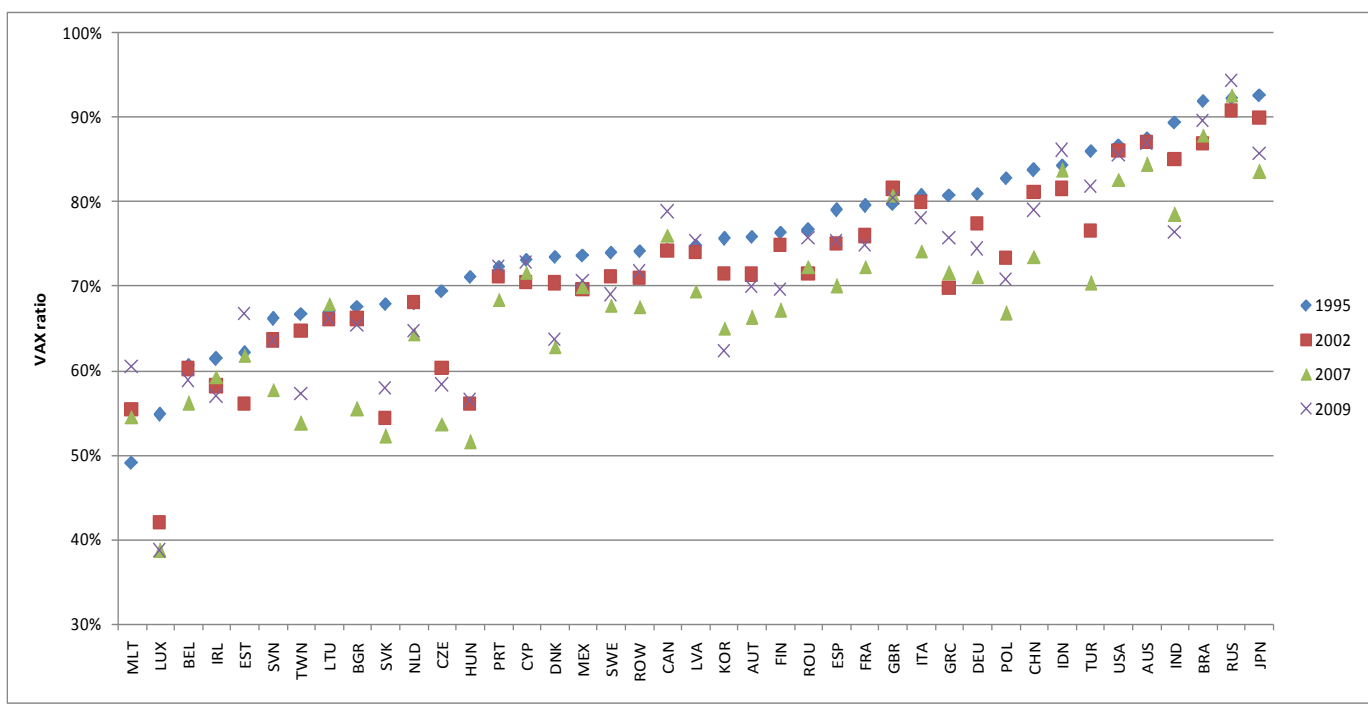

Figure 2. Value Added Exports (VAX) ratio by economy

Interestingly, the electrical equipment manufacturing (see Figure 3) shows some different trend and ranking from the one on aggregate level. There is no consistent trend observed: economies like US, Australia and UK experienced an increase in its value added content in their exports of electrical equipment while China, Korea and Japan had a decreasing VAX ratio in this sector. Opposite to the aggregate level, China has relatively low VAX ratio (34\% in 1995) in this sector and it dropped quickly from 35\% in 2002 to $27 \%$ in 2009. This is consistent with the finding by Koopman et al. (2010). Joining the WTO did increase China's exports in this sector; however, more openness in trade led to decrease in China's share of value added content. Similar to the aggregate level, there was generally a positive effect from GFC on the VAX ratio in the electrical equipment industry. China's VAX ratio also rebounded from $25 \%$ in 2007 to $27 \%$ in 2009. 


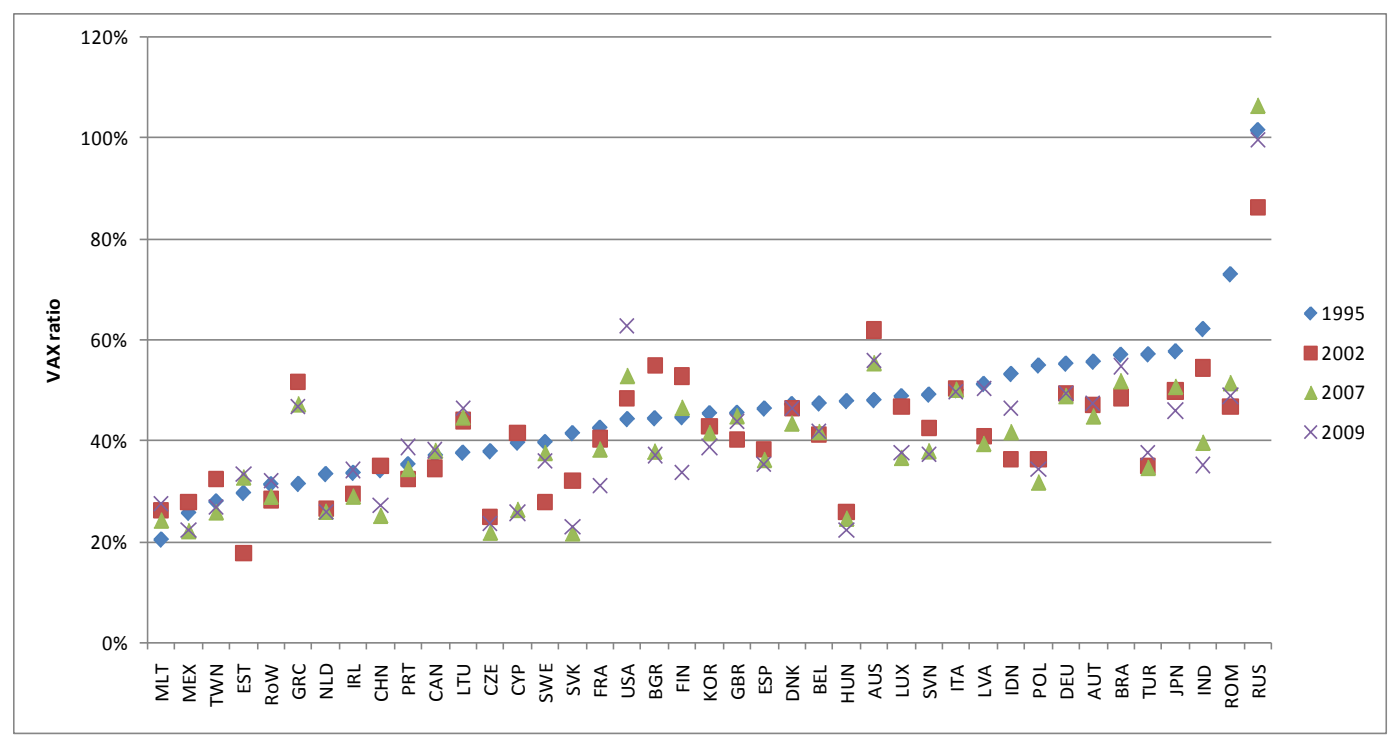

Figure 3. Value Added Exports (VAX) ratio of electrical equipment by economy

\subsection{How much does China specialize in producing electrical equipment?}

We adopt the revealed comparative advantage (RCA) index to measure how much China specializes in producing electrical equipment. As discussed in Section 3, we replace exports with VAX in Balassa's (1965) formula to compute RCA index according to equation (4). Table 1lists all the economies whose RCA indices of electrical equipment manufacturing are larger than one in the selected years.

Table 1. RCA and intermediate input VAX (VAXI) share

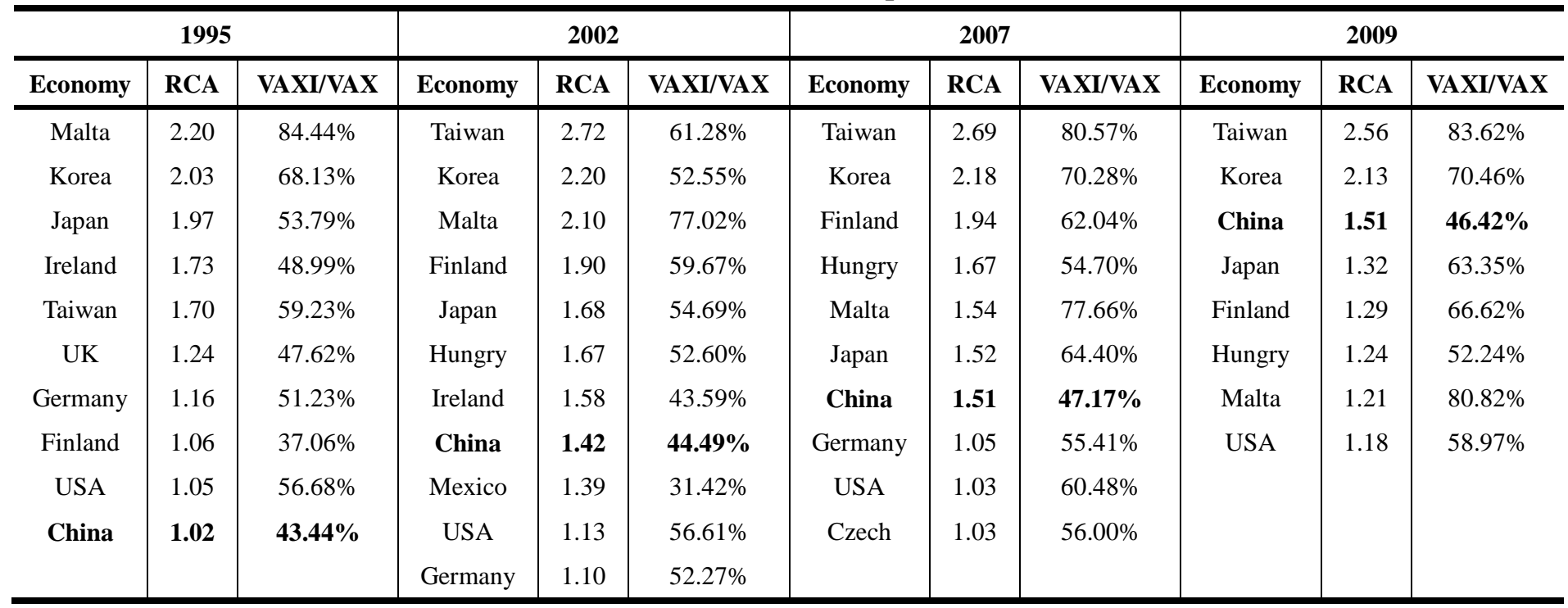

It is notable that China's RCA index kept increasing from 1995 to 2009 and it ranked the third by 2009. Taiwan and Korea have overwhelmingly large RCA compared to all the other economies; in particular, Taiwan grew rapidly from 1995 to 2002. It is also interesting to see that economies like Malta has very large RCA in electrical equipment manufacturing while US and Germany who are larger exporters in this industry ranked comparatively low in RCA index. In 2009, Germany's RCA was even less than one. US also shows increasing RCA index 
over the time while Japan, Germany and Korea decreased. This exactly reflects how globalization changes the comparative advantage and specialization of the economies involved. From 2002 to 2009, the specialization is more concentrated among fewer economies. The specialization is no longer identified by products, but by every stage of production, which is called "vertical specialization" in Hummels et al. (2001). As we discussed in Section 2, since many other Asian economies may also be important participants in this value chain, Table 1 may not be a complete list.

The third column for each year in Table 1 is a share of value added exports used as intermediate inputs in other economies' final production in the total VAX of this product (VAXI/VAX). It follows that one minus this share is the share of value added exports induced by foreign final demand of this product.

If we consider this share together with RCA index, then there may imply three types of economies in the global value chain. The first type (Type I) is economies like Malta, Korea and Taiwan. They are much specializing in producing the intermediate inputs (i.e. the parts) for electrical equipment as a large share of value added of their electrical products are used in other countries' electrical equipment production. China, Mexico and Ireland are more like the "assembly room" for the global electrical equipment production (Type II) as they seem to have large shares of domestic value added induced by the foreign final demand of this product. In other words, they are responsible for completing the last stage of producing electrical equipment, but there is not much value added from these economies as we can see in their VAX ratios (Figure 3). This finding is consistent with what Koopman et al. (2012) found for China's manufacturing sector in general. The third type (Type III) characterize economies such as US, Germany who are not too much specialized in producing the final products but still maintain quite a share of its VAX in serving the final demand elsewhere in the world. Such economies are in the upstream of the global value chain as they have comparative advantage in the final stage of production probably not because of low cost but high quality (core technology) in production.

There is also dynamics in which economies may switch their types across time. For example, Finland seemed to be in the Type III in 1995, but moved towards Type II in 2002 and probably towards Type I in 2009. Japan was more like Type II in 1995 and 2002, but towards Type I in 2009. Korea had the tendency to move towards Type II from Type I in 2002, but moved back to Type I in 2009. In this sense, China has been going deeper in its specialization of Type II from 1995 to 2009. The GFC seems to have little impact on changing the types of economies on the electrical equipment GVC.

Type III is definitely the high-end of this GVC, but it is hard to compare Type I and Type II. Type II is in a higher position than Type I in terms of the stage of production; however, in terms of the value added, Type I economies may perform more valuable activities than Type II economies. This will be discussed in the next section.

\subsection{How competitive is China in electrical equipment manufacturing?}

In this section, we intend to measure China's competitiveness in producing electrical equipment through two indicators: one is the competitiveness based on GVC income; the 
other is also based on GVC income but measures the contribution from the economy to the world production in terms of the value of its own final output. We call the latter one "contribution ratio".

Measured in GVC income, even an economy does not produce final goods, it still can add value to the global value chain through other valuable activities in any stage from other industries (Timmer et al. 2015). Figure 4 shows the four most "competitive" economies in electrical equipment manufacturing based on our competiveness calculation over the period of 1995-2009. China shows a rapid growth in its competitiveness while the other three economies were losing their "competitiveness" over time. In 2009, China shows overwhelmingly high "competitiveness" (25.21\%) over the other economies, which is comparable to the position of Japan in 1995. Then does it mean that China is now the most competitive economy in the world in electrical equipment manufacturing? To answer this question, we calculate another indicator, "contribution ratio".

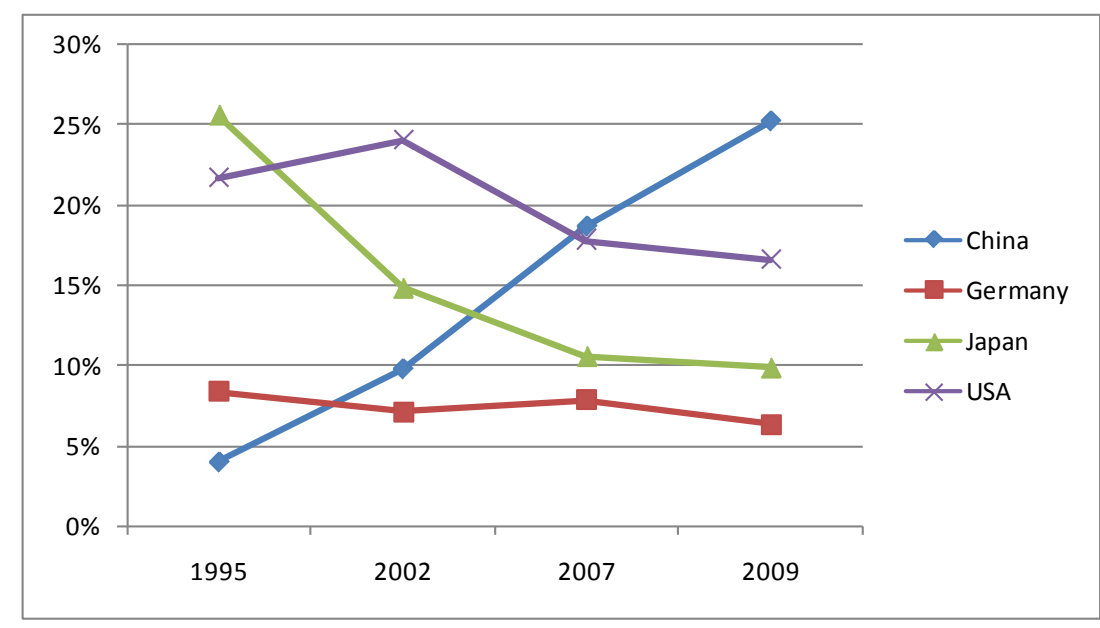

Figure 4. Competitiveness indicator across time for the selected economies

The contribution ratio is a new measurement defined as equation (5) in Section 3 of this paper. If the contribution ratio is larger than one, then the economy contributes more value than one unit of value of its own final products in this industry. This ratio actually compares the value added imports of the economy in producing this product with the value added exports from any industries in this economy contributing to any economies' production of this product. If the contribution ratio is larger than one, then the economy is a net value added exporter in this industry; otherwise it is a net value added importer. Then the net value added exporter is more competitive than the net value added importer in terms of one unit of value added.

A very large contribution ratio can be either due to a very small scale of final production or performing many high-value-added activities for the whole world industry. Therefore, we use both the competitiveness measure and the contribution ratio to identify the position of economies. 


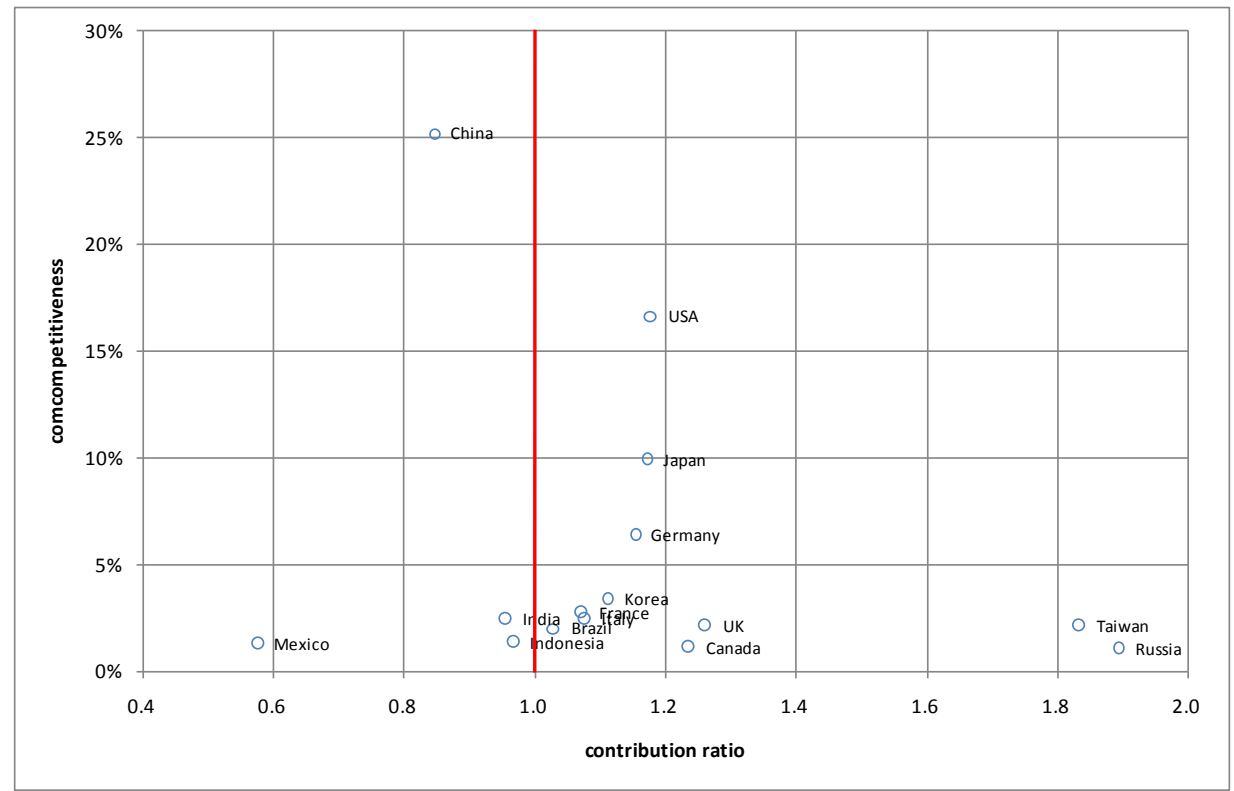

Figure 5. Competitiveness versus contribution ratio for selected economies in 2009

Figure 5 plots the competitiveness versus the contribution ratio for economies whose competitiveness measure is greater than $1 \%$ in 2009. The red line distinguishes the contribution ratio by " $>1$ ” or “ $<1$ ”. It is clear that US, Japan and Germany does not only have a high competitiveness, but also a contribution ratio which is greater than one. These economies really dominate the world electrical equipment manufacturing industry as they not only occupy a large share of value added in the world market, but also are net value added exporters by performing valuable activities throughout the production process in the world, such as R\&D, designing and marketing. China contributes the largest share of value added in this industry, but it is a net value added importer, which means that the outside world adds more value to China's electrical equipment industry than China's contribution of value added to the world electrical equipment industry. It is also notable that although China's competitiveness was much smaller in 1995 (4.03\%), its contribution ratio was higher than 2009, which was 0.91 in 1995. In other words, China becomes more competitive in producing electrical equipment on its home land than engaging in other economies' final production. Therefore, such competitiveness may come from the advantage attached to its domestic resources. We explore the structure of GVC income in the next section to verify and elaborate on this point.

It is also notable that there are some economies that have very big contribution ratios but relatively small competitiveness indicators, such as Taiwan and Russia. These economies are more competitive in adding value to other economies production of electrical equipment than producing the equipment in their domestic territories. This feature is consistent with the Type I economies as identified in Section 4.2.

\subsection{What is in China's GVC income?}

As is discussed in Section 4.2, China is closer to Type II economies that are "assembly room" for the world production. Therefore, China's electrical equipment manufacturing is an economy-industry-of-completion. Then how much domestic value China adds to its final electrical products? Table 2 shows domestic value added share in its total final output value of 
electrical equipment industry and compares it with other leading manufacturers.

Table 2. Domestic value added share in electrical equipment industry (\% of total final output value)

\begin{tabular}{c|cccc}
\hline & $\mathbf{1 9 9 5}$ & $\mathbf{2 0 0 2}$ & $\mathbf{2 0 0 7}$ & $\mathbf{2 0 0 9}$ \\
\hline China & $77.90 \%$ & $71.84 \%$ & $65.29 \%$ & $73.19 \%$ \\
Germany & $81.78 \%$ & $76.91 \%$ & $72.62 \%$ & $74.67 \%$ \\
Japan & $93.34 \%$ & $89.96 \%$ & $85.03 \%$ & $86.49 \%$ \\
USA & $85.43 \%$ & $87.79 \%$ & $84.44 \%$ & $88.60 \%$ \\
\hline
\end{tabular}

It is clear that China has lower domestic value added share than other three electrical equipment producing economies and the share is generally decreasing from 1995 to 2009, which confirms that China's specialization in the final production stage does not add as much value as that in US, Japan and Germany. However, the decreasing trend of domestic value added share is also observed in Japan and Germany. GFC seems to increase the domestic value added share for all the four economies. In particular, US shows a very unique trend such that its domestic value added share increased from 1995 to 2002 and then decreased from 2002 to 2007, and finally increased to $88.60 \%$ after the GFC and topped the four economies. This implies that US was actually gaining dominance in its electrical equipment manufacturing value chain even in the context of increasing global production fragmentation and GFC.

As discussed in Section 4.3, China has a large share of value added in the total value of world electrical equipment industry. However, the gross value added cannot fully reflect the "quality" of activities that an economy is engaged in the global value chain. Therefore, a further exploration of the GVC income is needed. Is the value added derived from cheap low-skilled labor compensation, capital investment, or the high-skilled activities? We make use of the social economic data in the WIOD to decompose the GVC income into several components: low-skilled labor compensation, medium-skilled labor compensation, high-skilled labor compensation and capital compensation ${ }^{9}$. As these data is not available for rest of the world (ROW), the average input shares of these four components in each sector's total output over the 40 economies are applied to ROW. Figure 6 shows the shares of the four components for China in 1995, 2002, 2007 and 2009. Figure 7 compares these shares with Germany, Japan, USA and the world in the selected years.

For China, the value added share of high-skilled labor in electrical equipment production is very small compared to the other three economies while the capital share is extraordinarily large (see Figure 7). The capital share grows the fastest from 1995 to 2009 for China and it reached $67 \%$ in 2009. The value added share of high-skilled labor increased slowly while the medium-skilled labor and low-skilled labor share decreased a little over the time. It is notable that China mainly substituted low-skilled labor with capital while other economies substituted low-skilled labor more with medium- and high-skilled labor. After the GFC, medium- and high-skilled labor share decreased while low-skilled labor and capital share increased, which shows a totally opposite trend to the other three economies. Germany and Japan have large

\footnotetext{
${ }^{9}$ Capital compensation in the WIOD is measured in terms of territory, therefore, it includes the compensation from foreign investment in the domestic capital stock.
} 
shares of value added coming from medium-skilled activities. US has the highest value added share of high-skilled activities and this share kept increasing quickly from 1995 to 2009, even with the GFC shocks.

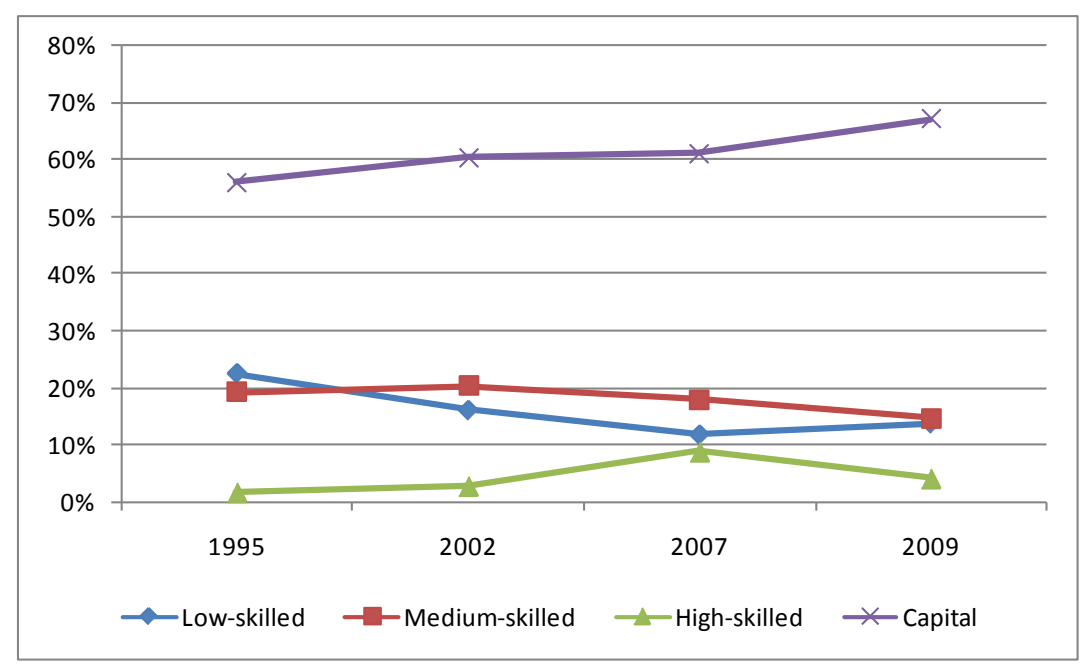

Figure 6. Value added structure of China's electrical equipment industry

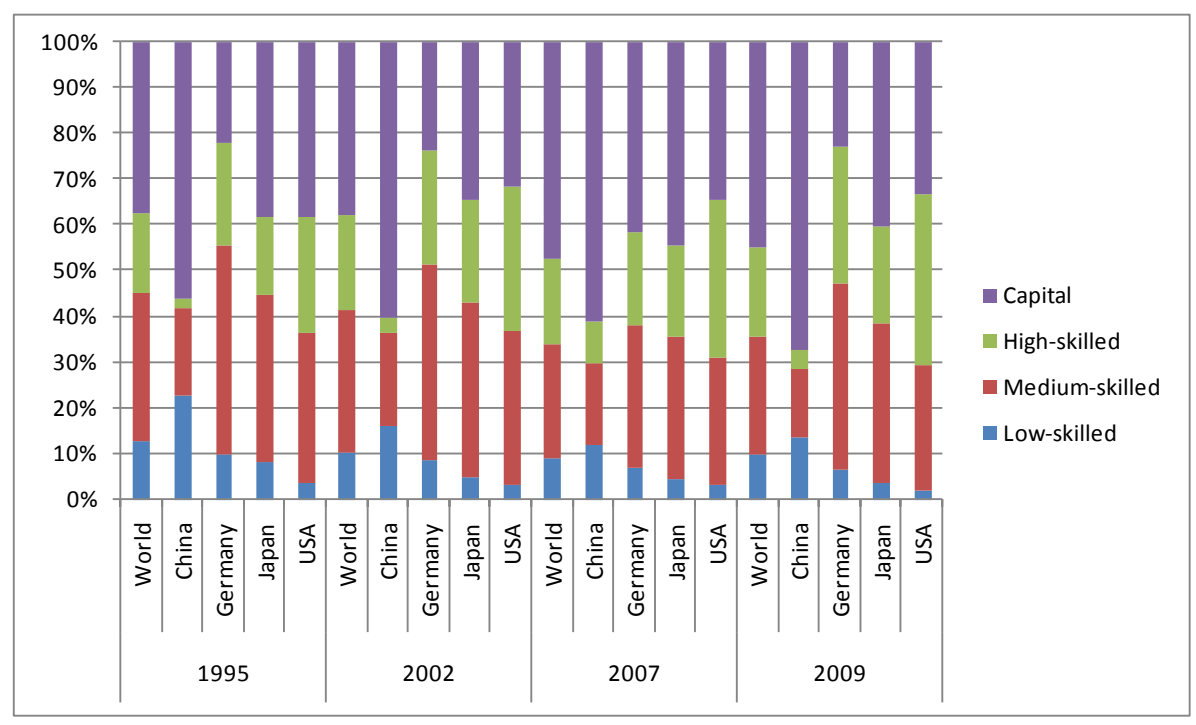

Figure 7. Value added structure of electrical equipment industry for different economies

Obviously, electrical equipment industry in China is absolutely capital intensive rather than labor intensive in terms of GVC income shares. But for the US, Japan and Germany, more than $60 \%$ of GVC income in this industry comes from labor compensation, especially medium- and high-skilled labor/activities. Again, this confirms that although China contributes the largest share of value added in the global value chains of electrical equipment production, it does not involve much high-skilled content in its production. Value added from labor of all skill content has limited contribution to China's "competitiveness" in the GVC income. Instead, capital is the major source of GVC income for China. This somehow is not consistent with what we find in Section 4.3 that China's competitiveness in producing electrical equipment may come from its "domestic resources". In general, capital has more mobility than labor and cannot necessarily be labeled as "domestic"; but note that "capital" in WIOD also includes those immobile resources such as natural resources and lands, etc. 
However, does it mean that the so-called demographic/labor dividend is not a major advantage for China's electrical equipment manufacturing? We will answer this question by measuring the number of workers involved in the industry on the domestic territory. Further, we will also explore the employment structure along the GVC. As pointed out by Timmer et al. (2013), due to the fact that "the mobility of labor is much lower than that of capital, GVC jobs (number of workers involved in GVC) will be closer to a national concept than GVC income”. Therefore, we calculate the "number of persons engaged" in electrical equipment manufacturing to explore the role of labor in this industry in China. Table 3 shows the percentage of persons involved in any stage of the electrical equipment manufacturing in all the GVCs for China, Germany, Japan and US. The table also contains its structure by sector and the real value added per person. ${ }^{10}$

Table 3. Employment structure and real value added per person

\begin{tabular}{|c|c|c|c|c|c|c|}
\hline & & $\begin{array}{l}\text { persons } \\
\text { involved in any } \\
\text { stage of the } \\
\text { electrical } \\
\text { equipment } \\
\text { manufacturing } \\
\text { in the world } \\
\text { GVCs (\% of } \\
\text { world industry } \\
\text { total) }\end{array}$ & $\begin{array}{l}\text { persons from } \\
\text { agriculture } \\
\text { sector involved } \\
\text { in electrical } \\
\text { equipment } \\
\text { manufacturing } \\
\text { (\% of the } \\
\text { economy) }\end{array}$ & $\begin{array}{l}\text { persons from } \\
\text { industrial } \\
\text { sector involved } \\
\text { in electrical } \\
\text { equipment } \\
\text { manufacturing } \\
\text { (\% of the } \\
\text { economy }^{1}\end{array}$ & $\begin{array}{l}\text { persons from } \\
\text { service sector } \\
\text { involved in } \\
\text { electrical } \\
\text { equipment } \\
\text { manufacturing } \\
\text { (\% of the } \\
\text { economy) }\end{array}$ & $\begin{array}{l}\text { value added } \\
\text { per person } \\
\text { (thousands } \\
\text { US\$ in } 1995 \\
\text { price) }\end{array}$ \\
\hline \multirow{4}{*}{1995} & China & $37.21 \%$ & $16.72 \%$ & $55.24 \%$ & $28.04 \%$ & 0.97 \\
\hline & Germany & $2.59 \%$ & $0.32 \%$ & $71.09 \%$ & $28.59 \%$ & 49.44 \\
\hline & Japan & $6.17 \%$ & $1.49 \%$ & $68.19 \%$ & $30.32 \%$ & 53.14 \\
\hline & USA & $7.09 \%$ & $0.35 \%$ & $59.76 \%$ & $39.89 \%$ & 38.78 \\
\hline \multirow{4}{*}{2002} & China & $42.54 \%$ & $16.23 \%$ & $49.54 \%$ & $34.23 \%$ & 1.62 \\
\hline & Germany & $2.60 \%$ & $0.27 \%$ & $62.37 \%$ & $37.36 \%$ & 35.18 \\
\hline & Japan & $4.83 \%$ & $1.19 \%$ & $65.53 \%$ & $33.27 \%$ & 39.95 \\
\hline & USA & $5.64 \%$ & $0.26 \%$ & $61.82 \%$ & $37.93 \%$ & 48.80 \\
\hline \multirow{4}{*}{2007} & China & $56.87 \%$ & $18.57 \%$ & $50.28 \%$ & $31.15 \%$ & 3.26 \\
\hline & Germany & $2.04 \%$ & $0.30 \%$ & $57.72 \%$ & $41.98 \%$ & 42.78 \\
\hline & Japan & $3.62 \%$ & $1.12 \%$ & $63.42 \%$ & $35.46 \%$ & 33.98 \\
\hline & USA & $3.65 \%$ & $0.30 \%$ & $62.06 \%$ & $37.65 \%$ & 53.01 \\
\hline \multirow{4}{*}{2009} & China & $58.86 \%$ & $17.76 \%$ & $50.26 \%$ & $31.98 \%$ & 2.62 \\
\hline & Germany & $1.84 \%$ & $0.26 \%$ & $59.43 \%$ & $40.30 \%$ & 49.86 \\
\hline & Japan & $2.73 \%$ & $1.38 \%$ & $60.84 \%$ & $37.78 \%$ & 53.07 \\
\hline & USA & $2.99 \%$ & $0.33 \%$ & $64.40 \%$ & $35.27 \%$ & 64.85 \\
\hline
\end{tabular}

Note: 1 . Industrial sector also includes mining, construction and utility supply, which is different from the "manufacturing” sector classified by Timmer et al. (2013).

China accounts for a large and increasing share of persons engaged in the world electrical equipment manufacturing industry, which contrasts to the other considered economies. Till 2009, almost $60 \%$ of the persons engaged in this industry are from China, in which persons

\footnotetext{
10 Since WIOD's data is in current price, we adjust the value added per person by using the annual inflation rate data from World Development Indicator (WDI) such that the value is based on 1995's price.
} 
from agriculture sector account for 16\%-17\%. In fact, this big bias towards agriculture sector in terms of workers engaged is the key difference of China from the other three economies. In other words, it is the development of agriculture sector that affects the development of electrical equipment manufacturing in China. It not only keeps labor in the agriculture sector from moving to other sectors, but also drags down the value added per worker.

Germany, Japan and US generally have more percentage persons involved from industrial sector and service sector. In particular, Germany shows a strong trend that workers shift from industrial sector to service sector while US shows an opposite trend. If we approximate this value added per person as "average real wage" for those persons engaged, this confirms that China has low cost of labor which contributes to its expansion of this industry. It is notable that China's value added per person engaged was only $4 \%-5 \%$ of the other three economies in 2009, but it has kept increasing gradually from 1995 to 2007. The value added per person decreased from 1995 to 2002 for Japan and Germany, but it rose from 2002 to 2009 to almost the same level as in 1995. US shows a strong upward trend in the average real wage across the time.

The GFC shock has a negative impact on the real wage of Chinese workers but a positive impact on that in the other three economies. It may be because that the GFC hit the employment much more than the GVC income in the developed economies while the workers involved in China actually increased even after the GFC shock. From Figure 6, it is likely that the increased number of workers is from low-skilled type, which drags down the average real wage. Furthermore, the share of high-skilled activities of China's GVC income did increase by 7.5 percentages from 1995 to 2007, but dropped by 5 percentages in the GFC (from 2007 to 2009) while this share kept increasing in the other three economies in the GFC (see Figure 7). Although China expanded its value added share in the world GVC during the GFC, it lost the opportunity to upgrade its GVC income structure. Therefore, it is a question whether such competitiveness gain is sustainable.

Table 4 documents the structure of person engaged in their own GVC for the above four economies. In particular, we calculate the percentage of foreign person involved and the percentage of domestic person from service sector.

Table 4. Employment structure of the four economy-industry-of-completion

\begin{tabular}{c|cc|cc|cc|cc}
\hline & \multicolumn{2}{|c|}{1995} & \multicolumn{2}{c|}{2002} & \multicolumn{2}{c|}{$\mathbf{2 0 0 7}$} & \multicolumn{2}{c}{$\mathbf{2 0 0 9}$} \\
\hline & $\mathbf{( 1 )}$ & $\mathbf{( 2 )}$ & $\mathbf{( 1 )}$ & $\mathbf{( 2 )}$ & $\mathbf{( 1 )}$ & $\mathbf{( 2 )}$ & $\mathbf{( 1 )}$ & $\mathbf{( 2 )}$ \\
\hline China & $2.55 \%$ & $26.57 \%$ & $6.86 \%$ & $32.77 \%$ & $8.61 \%$ & $30.90 \%$ & $7.62 \%$ & $31.78 \%$ \\
Germany & $41.41 \%$ & $27.16 \%$ & $44.32 \%$ & $35.04 \%$ & $55.00 \%$ & $38.94 \%$ & $49.55 \%$ & $36.43 \%$ \\
Japan & $33.82 \%$ & $29.78 \%$ & $31.81 \%$ & $32.37 \%$ & $34.74 \%$ & $33.69 \%$ & $35.01 \%$ & $36.52 \%$ \\
USA & $38.27 \%$ & $38.22 \%$ & $40.14 \%$ & $35.34 \%$ & $50.57 \%$ & $33.61 \%$ & $44.19 \%$ & $30.23 \%$ \\
\hline
\end{tabular}

Note: (1) Foreign person involved in the GVC of this economy (\% of total GVC persons engaged); (2) Domestic person engaged from service sector (\% of domestic persons engaged in GVC)

A low foreign participation rate in labor (column (1) in Table 4 for each year) of China further confirms that Chinese labor has the comparative advantage, especially the low-skilled workers as we see from the value added structure and the "average real wage". Germany and US got 
large share of foreign workers involved in their GVCs. While Germany and Japan witnessed a shift of domestic workers into service sector in their own GVCs, US seemed to have increased the share of their domestic workers from the industrial sector over the time. Such trends are also consistent with what we find in Table 3.

Together with the information of Table 2, Table 3 and Figure 7, we can see that China's competitiveness in electrical equipment production is mainly from the cheap low-skilled labor, and later the substitution of low-skilled labor with capital. Therefore, capital compensation adds most value to China's electrical equipment production. There is no much development of medium- and high-skilled activities in this industry for China. On contrary, as we can see from Germany, Japan and US the accumulation of medium- and high-skilled labor generates most value added for them in the world GVCs. Since labor has much lower mobility than capital, economies who have high-quality labor resources will be more likely to retain their competitiveness and climb up along the world GVCs than those who depend on capital investment. Therefore, China's competitiveness in electrical equipment manufacturing is not sustainable if China continues the current development pattern.

\section{Conclusion}

This paper takes a close look at China's electrical equipment manufacturing industry based on the "GVC income" approach (Timmer et al. 2013) by using the data from WIOD. More specifically, the study measures and compares China with other economies using the value added exports (VAX) ratio, the comparative advantage (the extent of specialization), the competitiveness, the structure of GVC income and employment for the electrical equipment manufacturing industry. In addition, a new measure "contribution ratio" is defined to describe the industry in the global context.

By calculating the RCA index and the structure of VAX, we identify that China has the comparative advantage in producing electrical equipment, especially in the final stage of production. This makes China a big "assembly room” of electrical equipment for the world. In terms of total contribution of value added to the world industry, China is competitive as it accounts for an absolutely large share in the world. However, if this share is compared with the value added of its final output, then China is found to be a net value added importer, which means that other economies add more value to China's electrical equipment industry than China's contribution of value added to the world electrical equipment industry. By further exploring the structure of GVC income, we find that capital contributes the majority of value added of this industry in China and it suppresses the growth of medium- and high-skilled labor/activities. Such development is different from other major electrical equipment producing economies that actually have expansion in the medium- and high-skilled activities rather than capital investment. Finally, China enjoys an extremely low cost of labor such that more than $50 \%$ of persons engaged in electrical equipment industry over the world are from China, which may justify its role of "assembly room" for the world. Although the GFC has shocked the world economy, it exerted a positive impact on the VAX ratio for most economies and electrical equipment industry in general. While China gained more share in the world electrical equipment GVC income, other leading economies increased their high-value-added content of their GVC income. 
Although China is a large economy-industry-of-completion, it does not mean that it has real "competitiveness" in the world. As we can see, China's competitiveness is easy to be taken over: capital can be mobile across economies; low-skilled labor resources will exhaust one day. In the context of increasing global production fragmentation, the final stage of production is no longer that important as many high-value-added activities are performed in the upstream, such as $R \& D$, industrial design. If China wants to retain its competitiveness in this industry, it should get more involved in these valuable activities to climb up along the global value chain. It is also notable that agriculture sector can be a drag for the development of electrical equipment manufacturing industry, or probably all the manufacturing industries. Therefore, to further develop manufacturing industries may finally fall upon upgrading the agriculture sector.

\section{Reference}

Antràs, P., Chor, D., Fally, T. and Hillberry, R. (2012). Measuring the Upstreamness of Production and Trade Flows. American Economic Review 102, 412-16.

Backer, K. D. and Miroudot, S. (2013). Mapping Global Value Chains. OECD Trade Policy Papers, No. 159, OECD Publishing. http://dx.doi.org/10.1787/5k3v1trgnbr4-en.

Balassa, B. (1965). Trade liberalisation and "revealed" comparative advantage 1. Manchester School, 33(2), 99-123.

Bullard, C W and Herendeen, R. (1975). The energy costs of goods and services. Energy Policy, 3(4), 268-278.

Bush, M J. (1981). The energy intensities of commodities produced in Canada. Energy 6, 503517.

Dietzenbacher, E., B. Los, Stehrer, R., Timmer, M. and de Vries, G. J. (2013). The Construction of World Input-Output Tables in the WIOD Project. Economic Systems Research 25, 71-98.

Fally, T. (2012). Production Staging: Measurement and Facts. University of Colorado Boulder, May.

Gereffi, G. and Fernandez-Stark, K. (2011). Global value chain analysis: a primer. Stark.

Hummels,D., Ishii, J. and Yi, K.-M. (2001). The Nature and Growth of Vertical Specialization in World Trade. Journal of International Economics 54, 75-96.

Jiang, X. and Liu, Y. (2015). Global value chain, trade and carbon: Case of information and communication technology manufacturing sector. Energy for Sustainable Development 25, 1-7.

Johnson, R. C. and Noguera, G. (2012). Accounting for Intermediates: Production Sharing and Trade in Value Added. Journal of International Economics 86, 224-36.

Koopman, R., Wang, Z., and Wei S.-J. (2010). Give credit where credit is due: tracing value added in global production chains. NBER working paper no. 16426. 
Koopman, R., Wang, Z., and Wei S.-J. (2012). How Much of Chinese Exports Is Really Made in China? Assessing Foreign and Domestic Value-added in Gross Exports. Journal of Development Economics 99, 178-89.

Koopman, R., Wang, Z., and Wei S.-J. (2014). Tracing Value-added and Double Counting in Gross Exports. American Economic Review 104, 459-94.

Manova, K. and Yu, Z. (2012). Firms and credit constraints along the value-added chain: processing trade in china. NBER working papers no.18561.

National Bureau of Statistics of China (NBSC), Annual Statistical Yearbook (2014), available at: http://data.stats.gov.cn.

Pick, H J. and Becker, P E. (1975). Direct and indirect use of energy and materials in engineering and construction . Applied Energy 1 (1), 31-51.

Timmer, M. P., Stehrer, B. Los, R. and de Vries, G. J. (2013). Fragmentation, Incomes and Jobs: An Analysis of European Competitiveness. Economic Policy 28, no. 76, 613-61.

Timmer, M. P., Dietzenbacher, E., Los, B., Stehrer, R., and de Vries, G. J. (2015). An illustrated user guide to the world input-output database: the case of global automotive production. Review of International Economics. DOI:10.1111/roie.12178

Vringer, K and Blok, K. (1995). The direct and indirect energy requirements of households in the Netherlands. Energy Policy 23 (10), 893-910.

World Bank, World Development Indicator (WDI), available at: http://data.worldbank.org/data-catalog/world-development-indicators/.

World Input-Output Database (WIOD), available at: http://www.wiod.org/new_site/home.htm.

World Trade Organization (WTO), merchandise statistics data, available at: https://www.wto.org/english/res_e/statis_e/merch_trade_stat_e.htm. 


\section{Appendix}

Table A.1 Economy code

\begin{tabular}{|c|c|}
\hline Code & Economy \\
\hline AUS & Australia \\
\hline AUT & Austria \\
\hline BEL & Belgium \\
\hline BRA & Brazil \\
\hline BGR & Bulgaria \\
\hline CAN & Canada \\
\hline CHN & China \\
\hline CYP & Cyprus \\
\hline CZE & Czech Republic \\
\hline DNK & Denmark \\
\hline EST & Estonia \\
\hline FIN & Finland \\
\hline FRA & France \\
\hline DEU & Germany \\
\hline GRC & Greece \\
\hline HUN & Hungary \\
\hline IND & India \\
\hline IDN & Indonesia \\
\hline IRL & Ireland \\
\hline ITA & Italy \\
\hline JPN & Japan \\
\hline KOR & Korea, Republic of \\
\hline LVA & Latvia \\
\hline LTU & Lithuania \\
\hline LUX & Luxembourg \\
\hline MLT & Malta \\
\hline MEX & Mexico \\
\hline NLD & Netherlands \\
\hline POL & Poland \\
\hline PRT & Portugal \\
\hline ROM & Romania \\
\hline RUS & Russia \\
\hline SVK & Slovak Republic \\
\hline SVN & Slovenia \\
\hline ESP & Spain \\
\hline SWE & Sweden \\
\hline TWN & Taiwan \\
\hline TUR & Turkey \\
\hline GBR & United Kingdom \\
\hline USA & United States \\
\hline RoW & Rest of the World \\
\hline
\end{tabular}




\begin{tabular}{|c|c|}
\hline Code & Sector \\
\hline c1 & Agriculture, Hunting, Forestry and Fishing \\
\hline c2 & Mining and Quarrying \\
\hline c3 & Food, Beverages and Tobacco \\
\hline $\mathrm{c} 4$ & Textiles and Textile Products \\
\hline c5 & Leather, Leather and Footwear \\
\hline c6 & Wood and Products of Wood and Cork \\
\hline c7 & Pulp, Paper, Paper, Printing and Publishing \\
\hline c8 & Coke, Refined Petroleum and Nuclear Fuel \\
\hline c9 & Chemicals and Chemical Products \\
\hline c10 & Rubber and Plastics \\
\hline c11 & Other Non-Metallic Mineral \\
\hline c12 & Basic Metals and Fabricated Metal \\
\hline c13 & Machinery, Nec \\
\hline c14 & Electrical and Optical Equipment \\
\hline c15 & Transport Equipment \\
\hline c16 & Manufacturing, Nec; Recycling \\
\hline c17 & Electricity, Gas and Water Supply \\
\hline c18 & Construction \\
\hline c19 & Sale, Maintenance and Repair of Motor Vehicles and Motorcycles; Retail Sale of Fuel \\
\hline c20 & Wholesale Trade and Commission Trade, Except of Motor Vehicles and Motorcycles \\
\hline c21 & Retail Trade, Except of Motor Vehicles and Motorcycles; Repair of Household Goods \\
\hline c22 & Hotels and Restaurants \\
\hline c23 & Inland Transport \\
\hline c24 & Water Transport \\
\hline c25 & Air Transport \\
\hline c26 & Other Supporting and Auxiliary Transport Activities; Activities of Travel Agencies \\
\hline c27 & Post and Telecommunications \\
\hline c28 & Financial Intermediation \\
\hline c29 & Real Estate Activities \\
\hline c30 & Renting of M\&Eq and Other Business Activities \\
\hline c31 & Public Admin and Defence; Compulsory Social Security \\
\hline c32 & Education \\
\hline c33 & Health and Social Work \\
\hline c34 & Other Community, Social and Personal Services \\
\hline c35 & Private Households with Employed Persons \\
\hline
\end{tabular}

